\title{
IDENTIFICATION OF ETHNOMEDICINAL COMPOUNDS AND ANTIMICROBIAL STUDIES OF SALVADORA PERSICA L. (SALVADORACEAE)
}

\author{
PRABHAKARAN K ${ }^{1 *}$, JOHN BRITTO S ${ }^{2}$, PREETHI J ${ }^{3}$
}

${ }^{1}$ Department of Chemistry, Government Arts College, Ayyar Malai, Kulithalai - 639 120, Tamil Nadu, India. ${ }^{2}$ Department of Rapinat Herbarium and Molecular Systematics, St. Joseph's College, Tiruchirappalli, Tamil Nadu, India. ${ }^{3}$ Department of Cellular and Molecular Biology, Lab-D05, Institute of Neurobiology, UNAM, Campus Juriquilla, Queretaro, Mexico. Email: kprabhakaran410@gmail.com

Received: 04 January 2019, Revised and Accepted: 02 March 2019

ABSTRACT

Objective: Salvadora persica L. is a dense foliaceous evergreen shrub or small tree with diversified medicinal properties. The objective of this work was to do a comparative study on phytochemical composition between different plant parts of S. persica collected from the southern region of India.

Methods: The phytochemical analysis of ethyl acetate fraction of ethanolic extracts from leaves, tender stems and tree bark of $S$. persica was done by gas chromatography-mass spectrometry/mass spectrometry (GC-MS/MS). Also, the anti-bacterial and anti-fungal activity of extracts was analyzed in vitro by Disc-diffusion method.

Results: GC-MS/MS analysis of S. persica showed 29 phytocompounds. Among them, except for eugenol, caryophyllene, benzyl isothiocyanate, oleic acid, and fatty acid, the remaining 24 phytocompounds were newly reported in the present study. For the first time, a maximum amount of benzyl isothiocyanate $(73.5 \%)$ was identified from tree bark extract of S. persica and this extract showed higher in vitro antimicrobial activity against grampositive, gram-negative bacteria and fungi than leaves and tender stems.

Conclusion: The study demonstrated that benzyl isothiocyanate could be the major antimicrobial component in S. persica.

Keywords: Salvadora persica, Toothbrush tree, Gas chromatography-mass spectrometry/mass spectrometry, Benzyl isothiocyanate, Antimicrobial activity.

(C) 2019 The Authors. Published by Innovare Academic Sciences Pvt Ltd. This is an open access article under the CC BY license (http://creativecommons. org/licenses/by/4. 0/) DOI: http://dx.doi.org/10.22159/ajpcr.2019.v12i4.31256

\section{INTRODUCTION}

Bioactive plant compounds have served as templates for several synthetic drugs, and precursors used in the production of semisynthetic drugs [1-4]. Salvadora persica of Salvadoraceae, popularly called Miswak, Arak, Rak and Toothbrush tree in the Arab and other tropical countries is an evergreen shrub or small sized tree with a life span of 25 years. In a floristic survey, $S$. persica has been recorded as one of the 61 ethnomedicinal plant species from the Aravalli hills of Mewar region of Rajasthan, India [5], though its distribution has been recorded elsewhere in India. The commercial $S$. persica sticks display antimicrobial action against both gram-positive (Streptococcus mutans and Streptococcus gordonii) and gram-negative (Porphyromonas gingivalis) oral bacteria [6]. Chewing sticks of $S$. persica have been used for centuries for tooth cleaning, and are recommended by the World Health Organization, in areas where their use is customary. A number of scientific studies have demonstrated that $S$. persica possesses anti-bacterial, anti-fungal, anti-viral, anti-cariogenic, anti-plaque, antiinflammatory, hypoglycemic, hypolipidemic, anti-osteoporosis, antioxidant, anti-ulcer, anti-convulsant, sedative and analgesic effects [7-11]. S. persica extracts exhibited antibacterial activities against 10 multidrugresistant bacterial clinical isolates other than oral pathogens in vitro [12]. A detailed survey was conducted in different parts of Saudi Arabia about the folklore uses, knowledge of local people and traditional healers to obtain information about this popular plant. Based on the results obtained, it was concluded that $S$. persica is a versatile medicinal plant used to treat enormous human and livestock ailments $[13,14]$.

Analytical methods such as gas chromatography-mass spectrometry (GC-MS) and liquid chromatography with tandem MS are now used for analysis of plant extracts to identify its phytochemicals [15-17]. The composition of the essential oil from the roots of $S$. persica collected in
Jordan and analyzed by GC and GC-MS showed seventeen compounds, the main constituents being benzyl isothiocyanate $(70 \%)$, limonene (9.4\%) and $\gamma$-pinene (8.7\%) [18]. In another study, GC-MS analysis of the volatile oil extract from leaves of $S$. persica was identified with following compounds: Benzyl nitrile, eugenol, thymol, isothymol, eucalyptol, isoterpinolene, and gamma-caryophyllene [19]. However, no study had compared between different parts of $S$. persica for its phytochemical constitution analytically by GC-MS.

The present investigation has adopted GC-MS to do a comparative study to identify and analyze phytocompounds in ethanolic extracts from different plant parts of $S$. persica (leaves, tender stems, and tree bark) collected from the southern region of India, elucidating their molecular formula, molecular weight and other data as revealed by GC-MS spectrum. Subsequently, the anti-bacterial and anti-fungal activity of $S$. persica extracts was studied in vitro by Disc-diffusion method.

\section{METHODS}

\section{General}

Solvents such as ethanol and ethyl acetate were used for the extraction of active compounds from plant materials which were purified before as mentioned in Harborne [20]. Ethyl alcohol was purified by drying with anhydrous potassium carbonate. It was filtered and distilled at $78^{\circ} \mathrm{C}$. Ethyl acetate was shaken with anhydrous potassium carbonate, filtered and pure ethyl acetate was distilled at $77^{\circ} \mathrm{C}[21,22]$.

\section{Plant material and extractions}

S. persica was collected from the dry deciduous forest of the Pulivallam reserved forest areas of Tiruchirapalli district, Tamil Nadu. The specimens were identified by Dr. S. John Britto at the Rapinat Herbarium, 
Tiruchirapalli (RHT) and the voucher specimens were deposited at the RHT.

Fresh leaves, tender stems, and tree bark of $S$. persica were dried for 7 days in a drafty place, protected from light. The dried parts were ground separately by an electric mill to the desired particle size (typically $<1 \mathrm{~mm}$ ) [23]. First finely ground leaf powder $(250 \mathrm{~g}) \mathrm{had}$ been taken in Soxhlet apparatus [20]. Solvent $(800 \mathrm{ml})$ had been taken in the $1000 \mathrm{ml}$ round bottom flask. The extraction was carried out for $8 \mathrm{~h}$. The same procedure was repeated thrice $(3 \times 250 \mathrm{~g}$ of leaf powder). The whole extract was collected, filtered and concentrated under reduced pressure. The dried extract was treated with $100 \mathrm{ml}$ of ethyl acetate. Ethyl acetate fraction was filtered and filtrate named as Sample A. The whole procedure was repeated for tender stems and tree bark separately. Extracts from tender stems and tree bark were named as Sample B and Sample C respectively.

\section{Microorganisms}

The test microorganisms of Gram-positive bacteria: Staphylococcus aureus, Streptococcus faecalis, Bacillus subtilis, Gram-negative bacteria: Pseudomonas aeruginosa, Eschericha coli, Klebsiella aerogenes, and Fungi: Candida albicans, Aspergillus niger, Penicillium sp., were obtained from National Chemical Laboratory, Pune and maintained by periodical subculturing on nutrient agar and Sabouraud dextrose medium for bacteria and fungi respectively

\section{Phytochemical screening by GC-MS}

GC-MS spectra were recorded using a Finnigan Matt GCQ Mass Spectrometer. Analysis of the plant extracts were performed at the Food Analysis Laboratory, Indian Institute of Crop Processing Technology, Thanjavur - 613 007, Tamil Nadu, India. These three samples A, B and C were separately analyzed in Finnigan Matt GCQ Mass Spectrometer.

\section{GC-MS program}

Column: Elite-1 (100\% Dimethyl polysiloxane), $30 \mathrm{~m} \times 0.25 \mathrm{~mm}$ ID $\times 1 \mu$ mdf, Equipment: GC Clarus 500 PerkinElmer, Carrier gas: Helium $1 \mathrm{ml} / \mathrm{min}$, Detector: Mass detector-Turbo mass gold-Perkin Elmer, Software-Turbomass 5-1. Sample injected: $1 \mu \mathrm{l}$ was injected with a Hamilton syringe to the GC-MS manually. Split: 10:1. Oven temperature program: $110^{\circ} \mathrm{C}-2 \mathrm{~min}$ hold up to $280^{\circ} \mathrm{C}$ at the rate of $5 \mathrm{deg} / \mathrm{min}-9 \mathrm{~min}$ hold, Injector temperature: $250^{\circ} \mathrm{C}$, Total GC time: $45 \mathrm{~min}$.

MS program

Library used: NIST Ver.2.1, Inlet line temperature: $200^{\circ} \mathrm{C}$, Source temperature: $200^{\circ} \mathrm{C}$

Electron energy: 70 ev, Mass scan: (m/z) 45-450, MS Time: 46 min.

\section{Antimicrobial analysis}

In vitro antimicrobial activity of the plant extracts (sample $\mathrm{A}, \mathrm{B}$, and $\mathrm{C}$ ) were separately analyzed by Disc-diffusion method [24]. Circular discs of $6 \mathrm{~mm}$ diameter were prepared from Whatman No. 1 filter paper and sterilized in an autoclave. Each paper disc was impregnated with plant extracts for overnight and placed in nutrient agar plates seeded with the test bacterium and Sabouraud dextrose plates seeded with the test fungi. The test bacterial plates were incubated at $37^{\circ} \mathrm{C}$ for $24 \mathrm{~h}$ and the test fungi plates were incubated at $25^{\circ} \mathrm{C}$ for $24 \mathrm{~h}$. After $24 \mathrm{~h}$ the zone of inhibition around each disc was measured and recorded. Each extract was tested four times to ensure the reliability of the result. The effect produced by the sample was compared with the effect produced by the positive control (reference standard: Ciprofloxacin $5 \mu \mathrm{g} /$ disc for bacteria and clotrimazole $10 \mu \mathrm{g} /$ disc for fungi).

\section{RESULTS}

Extensive studies on phytochemical investigation on $S$. persica reported amino acids and organic acids [25], heavy metals [26], inorganic constituents [27,28], glycosides [29], alkaloids [30], seed fat [31], fatty acids [32], phenols and forensic substances [28], essential oils [18,33], and benzyl amides [34]. However, the use of GC-MS is rather a few. In the present study, the phytocompounds present in $S$. persica plant extracts were investigated by GC-MS, the detailed elucidation of their retention time, molecular formula, molecular weight, and peak area in percentage as revealed by GCMS spectrum was separately shown in following Tables 1-3. The results showed that except eugenol, caryophyllene, benzyl isothiocyanate and oleic acid, many other phytocompounds from leaves (Fig. 1), tender stems and bark (Fig. 2) extracts were reported for the first time.

The in vitro antimicrobial activity as determined by the zone of inhibition [35] of $S$. persica leaves, tender stems, and bark extracts on some bacterial and fungal strains were shown in Table 4.

\section{DISCUSSION}

The comparative study of phytochemical reports from leaves, tender stems and tree bark of $S$. persica showed that n-hexadecanoic acid was present in higher concentration in leaves (51.6\%) than tender stems $(20.94 \%)$ and tree bark (8.88\%) extracts (Tables 1-3). The concentration of oleic acid was higher in tender stems (34.85\%) than tree bark (16.09\%) extract (Tables 2 and 3). Similarly, the tetradecanoic acid concentration was higher in tender stems (33.84\%) than tree bark (2.06\%) extract (Tables 2 and 3). The reported presence of eugenol and caryophyllene in S. persica leaves [19] and caryophyllene in $S$. persica stems extract $[29,36]$ were also identified in S. persica tender stems extract for the first time as shown in Table 2.

Many of the earlier papers showed the antimicrobial activity of $S$. persica [37-40]. The acid production of $C$. albicans was inhibited by benzyl

Table 1: GC-MS revealed the phytocompounds present in ethyl acetate fraction of $S$. persica leaves extract

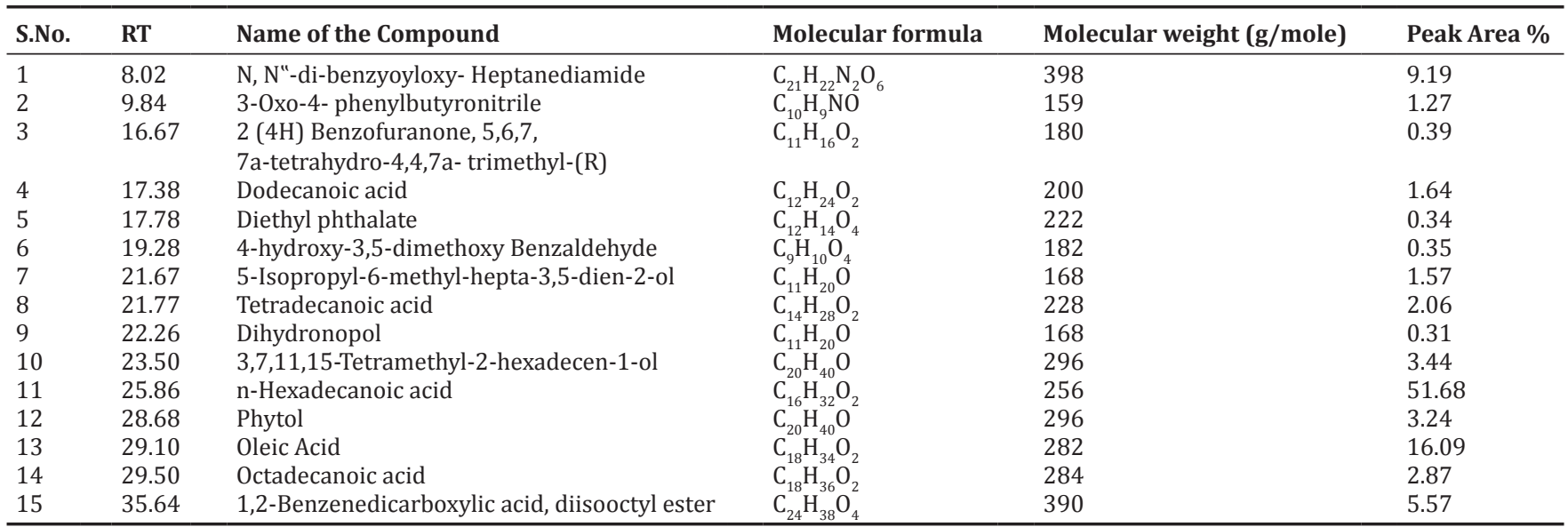

S. persica: Salvadora persica, GC-MS: Gas chromatography-mass spectrometry, RT: Retention time 


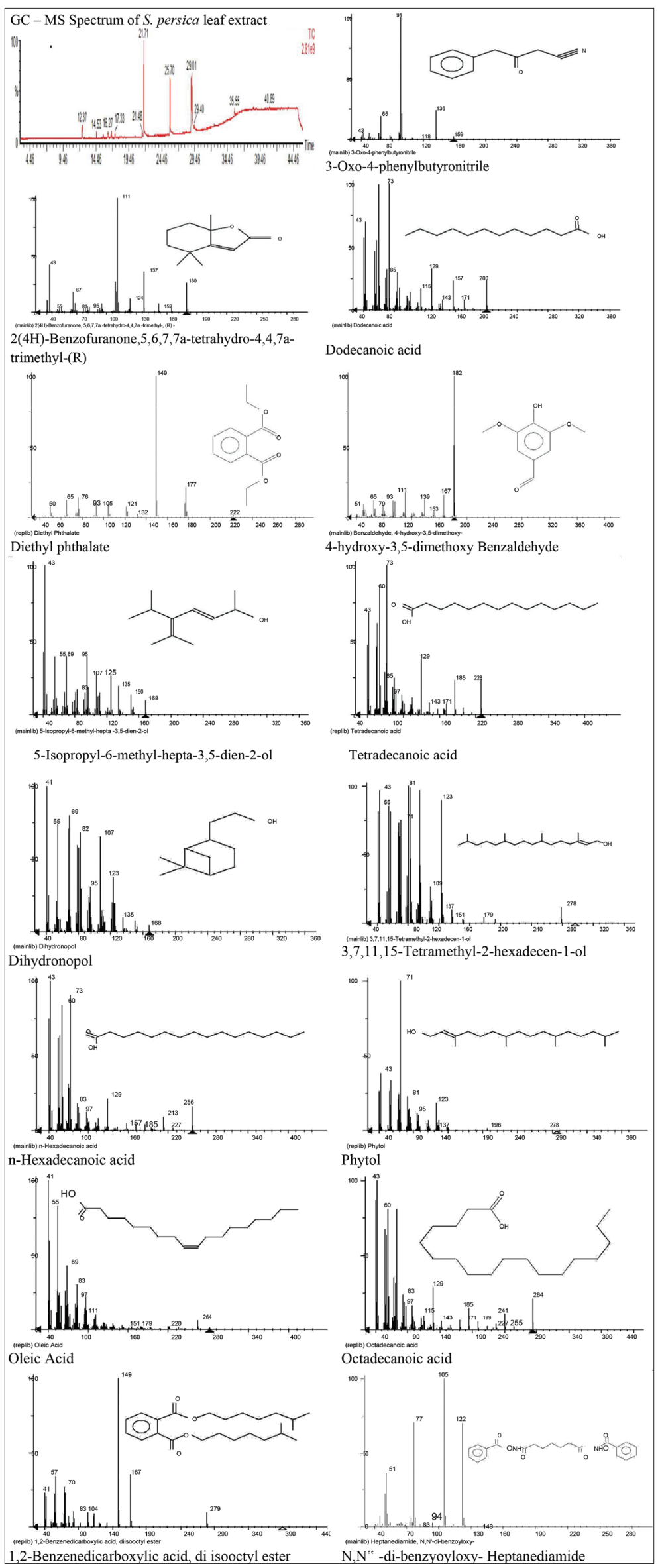

Fig. 1: Mass spectrum and structure of phytocompounds present in S. persica leaves extract 


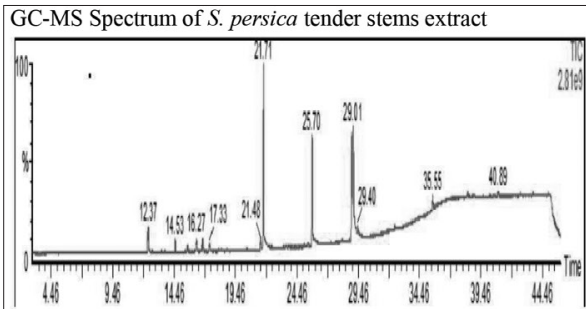

GC-MS Spectrum of S. persica tree bark extract
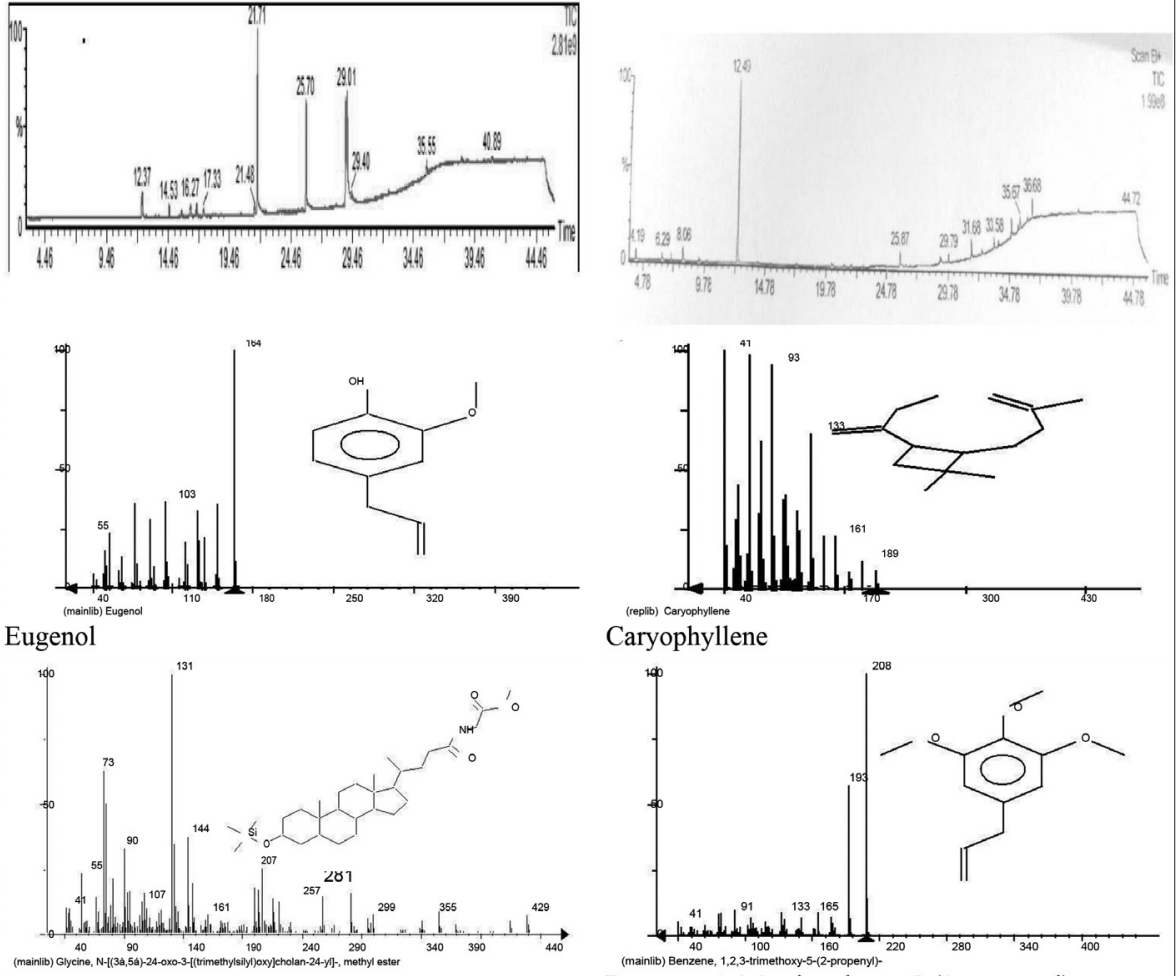

Glycine, $\mathrm{N}-[(3 \alpha, 5 \beta)-24-0 x 0-3-]$ [(trimethylsilyl)oxy]cholanBenzene, 1,2,3-trimethoxy-5-(2-propenyl) 24-yl]- methyl ester

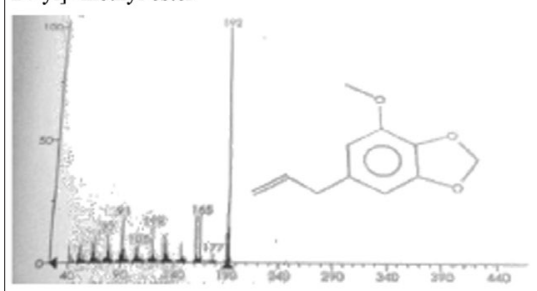

1,3-Benzodioxole,4-methoxy-6-(2-propenyl)
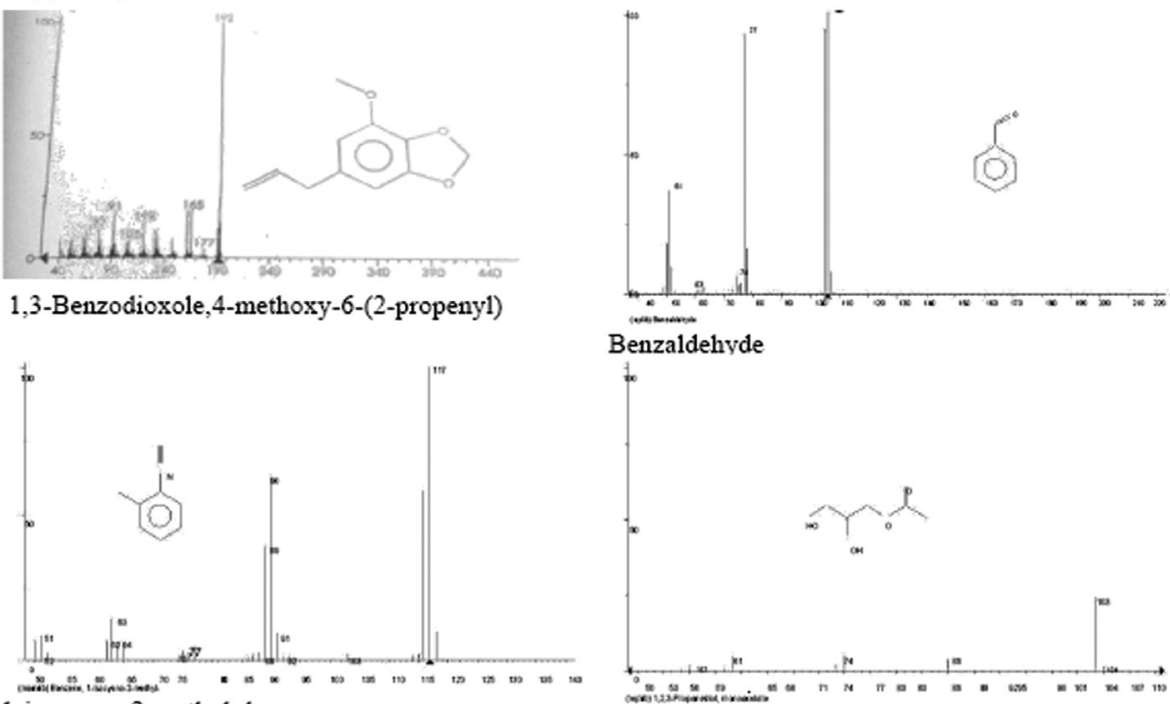

Benzaldehyde

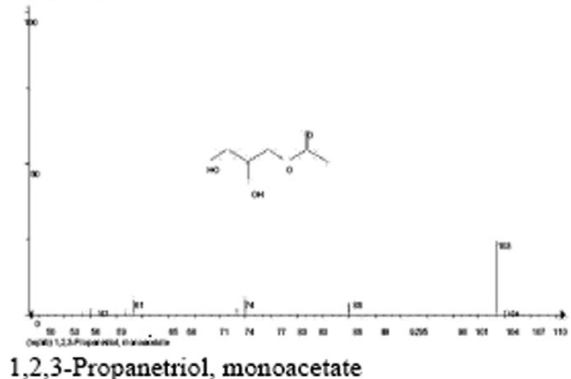

1-isocyano-2-methyl-benzene

1,2,3-Propanetriol, monoacetate

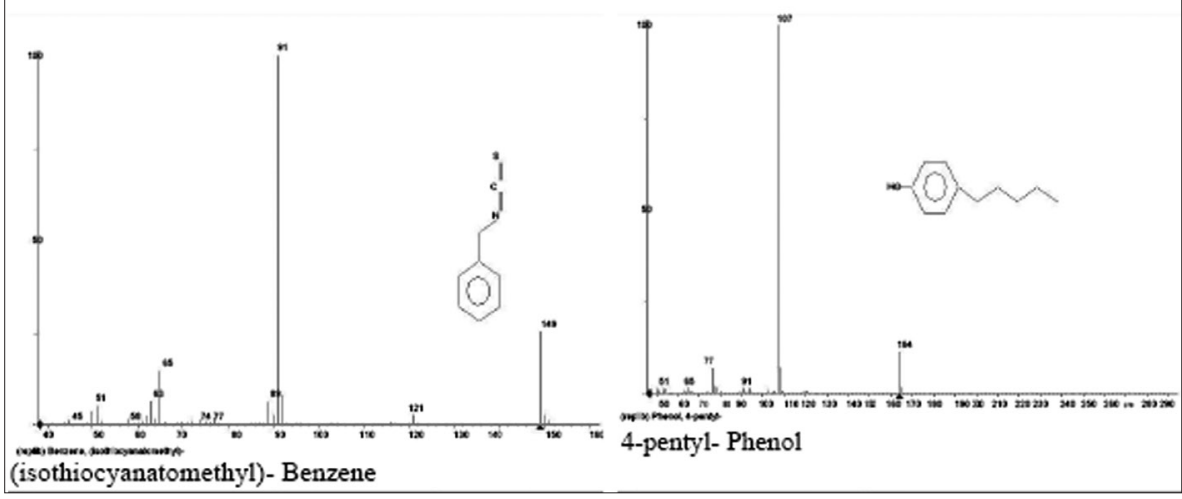

Fig. 2: Mass spectrum and structure of phytocompounds present in $S$. persica tender stems and tree bark extracts 
Table 2: GC-MS revealed the phytocompounds present in ethyl acetate fraction of $S$. persica tender stems extract

\begin{tabular}{|c|c|c|c|c|c|}
\hline S.No. & RT & Name of the Compound & Molecular formula & Molecular weight (g/mole) & Peak area \% \\
\hline 1 & 12.37 & Eugenol & $\mathrm{C}_{10} \mathrm{H}_{12} \mathrm{O}_{2}$ & 164 & 4.26 \\
\hline 2 & 14.53 & Caryophyllene & $\mathrm{C}_{15}^{10} \mathrm{H}_{24}^{12}$ & 204 & 1.43 \\
\hline 3 & 15.54 & $\begin{array}{l}\text { Glycine, } \mathrm{N}-[(3 \alpha, 5 ß)-24-\text { oxo-3-[(trimethylsilyl) oxy }] \\
\text { cholan-24-yl]- , methyl ester }\end{array}$ & $\mathrm{C}_{30} \mathrm{H}_{53} \mathrm{NO}_{4} \mathrm{Si}$ & 519 & 0.77 \\
\hline 4 & 16.27 & 4-methoxy-6-(2-propenyl)- 1,3-Benzodioxole & $\mathrm{C}_{11} \mathrm{H}_{12} \mathrm{O}_{3}$ & 192 & 2.48 \\
\hline 5 & 16.80 & 1,2,3-trimethoxy-5-(2-propenyl)- Benzene & $\mathrm{C}_{12}^{11} \mathrm{H}_{16}^{12} \mathrm{O}_{3}^{3}$ & 208 & 1.44 \\
\hline 6 & 21.71 & Tetradeconic acid & $\mathrm{C}_{14} \mathrm{H}_{2} 8 \mathrm{O}_{2}$ & 228 & 33.84 \\
\hline 8 & 29.01 & Oleic acid & $\mathrm{C}_{18}^{16} \mathrm{H}_{34} \mathrm{O}_{2}$ & 282 & 34.85 \\
\hline
\end{tabular}

S. persica: Salvadora persica, GC-MS: Gas chromatography-mass spectrometry, RT: Retention time

Table 3: GC-MS revealed the phytocompounds present in ethyl acetate fraction of $S$. persica tree bark extract

\begin{tabular}{|c|c|c|c|c|c|}
\hline S.No. & RT & Name of the compound & Molecular formula & Molecular weight (g/mole) & Peak area \% \\
\hline 1 & 6.30 & 1,2,3-Propanetriol, monoacetate & $\mathrm{C}_{5} \mathrm{H}_{10} \mathrm{O}_{4}$ & 134 & 3.15 \\
\hline 2 & 7.08 & 1-isocyano-2-methyl- Benzene & $\mathrm{C}_{8} \mathrm{H}_{7} \mathrm{~N}$ & 117 & 2.18 \\
\hline 3 & 12.50 & Benzene, isothiocyanatomethyl Or (Benzyl isothiocyanate) & $\mathrm{C}_{8}^{\circ} \mathrm{H}_{7} \mathrm{NS}$ & 149 & 73.53 \\
\hline 4 & 14.19 & Benzenamine, 4-butyl & $\mathrm{C}_{10}^{0} \mathrm{H}_{15} \mathrm{~N}$ & 149 & 0.65 \\
\hline 5 & 20.28 & 4-pentyl- Phenol & $\mathrm{C}_{11}^{10} \mathrm{H}_{16} \mathrm{O}$ & 164 & 1.69 \\
\hline 6 & 25.86 & n-Hexadecanoic acid & $\mathrm{C}_{16}^{11} \mathrm{H}_{32} \mathrm{O}_{2}$ & 256 & 8.88 \\
\hline
\end{tabular}

S. persica: Salvadora persica, GC-MS: Gas chromatography-mass spectrometry, RT: Retention time

Table 4: In vitro antimicrobial activities of $S$. persica - leaves, tender stems and bark extracts

\begin{tabular}{|c|c|c|c|c|c|}
\hline \multirow[t]{2}{*}{ S. No. } & \multirow[t]{2}{*}{ Name of the microorganism } & \multicolumn{3}{|l|}{ Zone of inhibition (mm) } & \multirow[t]{2}{*}{ Standard } \\
\hline & & $\begin{array}{l}\text { Sample A } S \text {. persica leaves } \\
\text { extract }\end{array}$ & $\begin{array}{l}\text { Sample B } S \text {. persica tender } \\
\text { stems extract }\end{array}$ & $\begin{array}{l}\text { Sample C } S \text {. persica } \\
\text { bark extract }\end{array}$ & \\
\hline 1 & Staphylococcus aureus (NCIM 2079) & 12 & 15 & 14 & 25 \\
\hline 2 & Bacillus subtilis (NCIM 2063) & 11 & 10 & 18 & 25 \\
\hline 3 & Staphylococcus faecalis (NCIM 2080) & 14 & 12 & 17 & 25 \\
\hline 4 & Escherichia coli (NCIM 2065) & 0 & 14 & 25 & 25 \\
\hline 5 & Pseudomonas aeruginosa (NCIM 2036) & 16 & 21 & 24 & 28 \\
\hline 6 & Klebsiella aerogens (NCIM 2098) & 20 & 10 & 20 & 30 \\
\hline 7 & Aspergillus niger (NCIM 1005) & 0 & 10 & 30 & 18 \\
\hline 8 & Penicillum sp. (NCIM 3106) & 8 & 15 & 15 & 16 \\
\hline 9 & Candida albicans (NCIM 3102) & 12 & 14 & 32 & 15 \\
\hline
\end{tabular}

Standard: Ciprofloxacin - $5 \mu \mathrm{g}$ /disc for bacteria, Clotrimazole - $10 \mu \mathrm{g} /$ disc for fungi. S. persica: Salvadora persica

isothiocyanate solutions in 10, 50 and $100 \mu \mathrm{g} / \mathrm{ml}$ concentrations [37] and this volatile oil benzyl isothiocyanate were extracted from roots of $S$. persica by Sofrata et al. [41]. Also, Bader et al. [18] identified a high concentration of benzyl isothiocyanate $(70 \%)$ from $S$. persica root extracts. Together benzyl isothiocyanate found in the root of $S$. persica showed higher antimicrobial activity against gram-negative bacteria [41]. A recent study evidenced the antimicrobial component benzyl isothiocyanate in the oral cavity of humans chewing miswak sticks [42]. In the present study, this benzyl isothiocyanate was found higher in $S$. persica tree bark extract compared to leaves and tender stem extracts (Table 3). The concentration of benzyl isothiocyanate in tree bark was $73.5 \%$ which could be mainly responsible for the higher antimicrobial property of $S$. persica as shown in Table 4.

\section{Structure of Benzyl isothiocyanate}<smiles>S=C=NCc1ccccc1</smiles>

The overall results of this investigation in $S$. persica indicated that the extracts from leaves, tender stems, and tree bark hold a potential source of plant drugs. They appear most promising not only as a blueprint for antimicrobial drugs but also have several valuable phytochemicals for other ailments.

\section{CONCLUSION}

The presence of several medicinal phytocompounds justifies the traditional ethnopharamacological uses of the plant, $S$. persica. The quantum of phytochemical data added more knowledge to the existing data about $S$. persica. Investigation in the future can take these data as starting points of drug developments. High-throughput screening along with combinational biosynthesis will have to be devised for better use of $S$. persica natural products. Also, automated real-time polymerase chain reaction process will enable the proper quality control and genetic identification of a rich variety of Salvadora species for its manifold medicinal uses.

\section{CONFLICT OF INTEREST}

The authors declare no conflict of interest.

\section{REFERENCES}

1. Verdine GL. The combinatorial chemistry of nature. Nature 1996;384:11-3.

2. Wessjohann LA. Synthesis of natural-product-based compound libraries. Curr Opin Chem Biol 2000;4:303-9. 
3. Newman DJ, Cragg GM, Snader KM. Natural products as sources of new drugs over the period 1981-2002. J Nat Prod 2003;66:1022-37.

4. Chathurdevi G, Umagowrie S. Potent bioactive metabolites of Casuarina junghuhniana MIQ. Roots - A therapeutic approach. Int J Pharm Pharm Sci 2017;9:158-65.

5. Katewa SS, Chaudhary BL, Jain A. Folk herbal medicines from tribal area of Rajasthan, India. J Ethnopharmacol 2004;92:41-6.

6. Uddin I, Kanatas A. Oral health: Salvadora persica. Br Dent J 2014;216:98.

7. Ezmirly ST, Cheng JC, Wilson SR. Saudi Arabian medicinal plants: Salvadora persica. Planta Med 1979;35:191-2.

8. Al-Fatimi M, Wurster M, Schröder G, Lindequist U. Antioxidant, antimicrobial and cytotoxic activities of selected medicinal plants from yemen. J Ethnopharmacol 2007;111:657-66.

9. Khatak M, Khatak S, Siddqui AA, Vasudeva N, Aggarwal A, Aggarwal P. Salvadora persica. Pharmacogn Rev 2010;4:209-14.

10. Haque MM, Alsareii SA. A review of the therapeutic effects of using miswak (Salvadora persica) on oral health. Saudi Med J 2015;36:530-43.

11. Aumeeruddy MZ, Zengin G, Mahomoodally MF. A review of the traditional and modern uses of Salvadora persica L. (Miswak): Toothbrush tree of prophet Muhammad. J Ethnopharmacol 2018;213:409-44.

12. Al-Ayed MS, Asaad AM, Qureshi MA, Attia HG, AlMarrani AH. Antibacterial activity of Salvadora persica L. (Miswak) extracts against multidrug resistant bacterial clinical isolates. Evid Based Complement Alternat Med 2016;2016:7083964

13. Toyang NJ, Wanyama J, Nuwanyakpa M, Django S. Ethnoveterinary Medicine. A Practical Approach to the Treatment of Cattle Diseases in sub-Saharan Africa. Wageningen: Agromisa Foundation and CTA; 2007.

14. Sher H, Nasser AM, Wijaya L. Ethnobotanical and antibacterial potential of Salvadora persica. A well known medicinal plant in Arab and Unani system of medicine. J Med Plant Res 2011;5:1224-9.

15. Halket JM, Zaikin VG. Derivatization in mass spectrometry-1. Silylation. Eur J Mass Spectrom (Chichester) 2003;9:1-21.

16. Halket JM, Waterman D, Przyborowska AM, Patel RK, Fraser PD, Bramley PM. Chemical derivatization and mass spectral libraries in metabolic profiling by GC/MS and LC/MS/MS. J Exp Bot 2005;56:219-43

17. Gupta R, Singh RL, Dwivedi N. In vitro antioxidant activity and GCMS analysis of the ethanolic extracts of Terminalia bellerica roxb (baheda). Int J Pharm Pharm Sci 2016;8:275-82.

18. Bader A, Guido F, Pier LC, Ivano M. The composition of the root oil of Salvadora persica L. J Essent Oil Res 2002;14:128-9.

19. Alali F, Al-Lafi T. GC-MS analysis and bioactivity testing of the volatile oil from the leaves of the toothbrush tree Salvadora persica L. Nat Prod Res 2003;17:189-94.

20. Harborne JB. Phytochemical Methods: A Guide to Modern Techniques of Plant Analysis. $3^{\text {rd }}$ ed. London: Chapman \& Hall; 1998

21. Riddick JA, Burger WB. Organic solvents. In: Weiss Berger A, editor. Techniques of Chemistry. $3^{\text {rd }}$ ed., Vol. 2. New York: Willey-Inter Science; 1970.

22. Vogel AI, Tatchell AR, Furnis BS. Vogel's Textbook of Practical Organic Chemistry. $5^{\text {th }}$ ed. London: Pearson Education; 1989. p. 165-8, 397-403.

23. Gudzic B, Nedeljkovic J, Dordevic S, Čomor JJ. Composition and anti-microbial activity of essential oil of hyperici herb (Hypericum perforatum L.) from Vlasina region. Phys Chem Technol 1997;1:47-51.

24. Maruzella JC, Henry PA. The antimicrobial activity of perfume oils. J Am Pharm Assoc 1958;47:471-6.

25. Bharucha FR, Rangnekar PV. Studies in free amino acids and organic acids of halophytes of Bombay. Naturwissenschaften 1957;44:469.

26. Raj K, Agrawal Y. Heavy metal contents of the leaf-galls of Salvadora persica Linn. Sci Cult 1979;45:35-6.

27. El Sayed ZA. Identification of inorganic constituents of Salvadora persica using spectroscopic techniques. Bull Natl Res Centre (Egypt) 1995;20:163-70.

28. Bahabri F, Jeddah. Application of spectroscopic techniques for the identification of organic and inorganic constituents of Salvadora persica from Saudi Arabia. Physica A 2000;276:346-51.

29. Kamel MS, Ohtani K, Assaf MH, Kasai R, El-Shanawani MA, Yamasaki K, et al. Lignan glycosides from stems of Salvadora persica. Phytochemistry 1992;31:2469-71.

30. Malik S, Ahmad SS, Haider SI, Muzaffar A. Salvadoricine - A new indole alkaloid from the leaves of Salvadora persica. Tetrahedron Lett 1987;28:163-4

31. Khan SA, Qureshi MI, Bhatty MK. Fatty acids of indigenous resources for possible industrial applications. IV. Species of Salvadoraceae family. Pak J Sci Ind Res 1972;15:402-4

32. Hosamani KM, Pattanashettar RS. Salvadora persica seed oil: A rich source of oil and minor source of cyclopropenoid fatty acids. J Med Aromat Plant Sci 2002;24:713-5.

33. Galletti GC, Chiavari G, Kahie YD. Pyrolysis/gas chromatography/iontrap mass spectrometry of the 'tooth brush' tree (Salvadora persica L.). Rapid Commun Mass Sp 1993;7:651-5.

34. Khalil AT. Benzylamides from Salvadora persica. Arch Pharm Res 2006;29:952-6.

35. Khan I, Chauhan N, Chauhan PK, Khan MA. Evaluation of phytoconstituents, and antimicrobial and antioxidant activity of Juglans regia from Kashmir region. Asian J Pharm Clin Res 2019;12:89-92.

36. Alali F, Hudaib M, Aburjai T, Khairallah K, Al-Hadidi N. GC-MS analysis and antimicrobial activity of the essential oil from the stem of the Jordanian toothbrush tree Salvadora persica. Pharm Biol (Lisse, Netherlands) 2004;42:577-80.

37. Almas K, Skaug N, Ahmad I. An in vitro antimicrobial comparison of miswak extract with commercially available non-alcohol mouthrinses. Int J Dent Hyg 2005;3:18-24

38. Darmani H, Nusayr T, Al-Hiyasat AS. Effects of extracts of miswak and derum on proliferation of Balb/C $3 \mathrm{~T} 3$ fibroblasts and viability of cariogenic bacteria. Int J Dent Hyg 2006;4:62-6.

39. Siddiqui S, Khan SS, Ansari AH. Antimicrobial activity of Salvadora persica. J Ultra Chem 2006;2:193-6.

40. Abhary M,Al-Hazmi AA. Antibacterial activity of Miswak (Salvadora persica L.) extracts on oral hygiene. J Taibah Univ Sci 2016;10:513-20.

41. Sofrata A, Santangelo EM, Azeem M, Borg-Karlson AK, Gustafsson A, Pütsep K. Benzyl isothiocyanate, a major component from the roots of Salvadora persica is highly active against gram-negative bacteria. PLoS One 2011;6:e23045.

42. Albabtain R, Azeem M, Wondimu Z, Lindberg T, Borg-Karlson AK, Gustafsson A. Investigations of a possible chemical effect of Salvadora persica chewing sticks. Evid Based Complement Alternat Med 2017;2017:2576548 